\title{
Accessibility of Elderly Citizens to Basic Facilities In Akure Metropolis in Nigeria
}

\author{
Musilimu Adeyinka Adetunji \\ Department of Geography, Faculty of Social Sciences, Federal University Lokoja, Lokoja, Nigeria
}

Corresponding e-mail: musilimuadetunji@yahoo.com; maadetunji@yahoo.com

\section{Article info:}

Received: 24-04-2020, Revised: 29-04-2020; 02-05-2020, Accepted: 04-05-2020

\begin{abstract}
This study examined the accessibility of elderly citizens to some basic services in Akure metropolis. This was carried out with a view to determine the patterns of distribution and accessibility of these services in the city. Primary and secondary data were employed for this study. Geographical Positioning System was used to capture the coordinates of important locations and of some basic facilities such as Public Tertiary Hospital, Primary Health care centre and banks in the city. Nearest Neighbour Analysis was used to calculate the mean distance travel to some basic services from 13 major localities in Akure metropolis. Descriptive and inferential statistics were employed to analyse the data. Finding reveals that some basic facilities are not evenly distributed across different localities in Akure. The mean distance travel to Public Tertiary Hospital is $3.36 \mathrm{kms}$. The pattern of distribution of Public Tertiary Hospital is dispersed rather than random. More than $60 \%$ of the elderly rely on public transport services for their trip to access some basic facilities in the city. Traffic delay was ranked highest $(66 \%)$ among the problems militating against the effective utilization of urban facilities in Akure metropolis. The study recommends that more basic facilities should be provided in localities where such services are lacking. This would reduce long distance trip to these facilities in the city. The study concludes that better transport services should be made available at reasonable transport fares in order to promote accessibility of the elderly and other segments of the population to urban facilities in Akure and similar other cities in Nigeria.
\end{abstract}

Keywords: Senior Citizens, Urban Services, Transport, Accessibility, Planning.

\section{Introduction}

The provision of efficient and reliable transport system is highly essential to the general populace, particularly the less privileged citizens, who include the poor, the elderly, the young and the disabled with less access to personal means of transportation for their day to day transactions (Adesanya, Adeniji and Daramola, 2002: p.239; Duvarci, Yigitcanlar, Alver, and Mizokami, 2010; Giuliano, 2005 as cited in Yi Zhang, Wei Wu, Qian He, and Chaoyang $\mathrm{Li}, 2018$ : p.702). Studies have shown that good mobility is associated with a better quality of life (Mussel White and Haddad, 2010). Mobility of senior citizens is highly imperative because they are becoming a larger proportion of the society and participate in different activities such as escorting their grandchildren to school, visiting health care providers or relatives, and providing voluntary services which require daily commuting(Mackett, 2014: p.5). Senior citizens need to have more access to basic facilities distributed over space and time, within short distance and at minimal cost in order to perform their civic responsibilities (Mengying Cui and David Levinson, 2018: p.661).

The concept of accessibility, with respect to transportation can be defined as ease with which an individual can reach valuable destinations. This can be measured in terms of the number of opportunities that can be reached within a given threshold (Mengying Cui and David Levinson, 2018: p.661). Many studies have used mode choice of transportation to determine the level of accessibility of people to some basic facilities located in geographical space 
(Olawole and Aloba, 2014: p.110.,Owen and Levinson, 2014). Owen and Levison (2014) further affirmed that the number of destinations reachable within a given travel time is the most directly comparable across cities. This implies that locations of facilities reachable within a short time are more accessible than those reachable for longer time. Geurs and Wee (2004: p131) have observed that accessibility measures can be used as a social indicator if it shows the availability of social and economic opportunities such as jobs, foods, health and social services provided in any geographical space. Accessibility can be viewed in the dimensions of availability, accommodation, affordability and acceptability(Penchansky and Thomas, 1981 as cited in Yang Ya-ting., Iqbal Usman., Ko Hua-Lin., Wu Chia-Rong,. Chiu Hsien -Tsai Chiu., Lin Yi- Chieh., Lin Wender and Hsu Yi-Hsin Elsa Hsu, 2015: p. 223).

In a study of elderly accessibility to health care facilities in four cities of the United States of America in 2004, Fitzpatric., Powe., Cooper and Ives (2004), reported that the most common barrier to access health care services was the doctor's lack of response to concern, and this accounted for $32.9 \%$. Medical treatment for their illness was ranked second $(22.3 \%)$, while transport problem recorded $21.1 \%$. Street safety accounts for $19.6 \%$ fear of discovering a serious illness and unneeded test accounts for $18.1 \%$ and $16.3 \%$ respectively. In a similar study in Montreal Island, Paez., Mercado., Farber., Morency .,and Roorda (2010) evaluated the accessibility of senior and non-senior residents to health care facilities. The findings revealed that older residents of Montreal Island tend to be significantly less mobile than people of other age cohorts. The combination of an average trip length estimates with the spatial distribution of health care facilities indicate that despite being more mobile, suburban residents tend to have lower levels of accessibility compared to central city residents.

In a study carried out by Srichuae, Nitivattanaon and Rnjith (2016: p.31) on factors determining elderly mobility in Bangkok, it was reported that short distances promoted mobility to access low order public spaces that serves activities of daily life and leisure ( i.e daily shopping, religious activities, and recreation). On the other hand, long travel distances enabled access to essential activities in higher order public spaces such as hospital and stadium. In an assessment of elderly accessibility to socio-economic facilities in six geopolitical zones in Nigeria, Adesanya et. al.(2002: p.240) affirmed that limited access to some urban facilities such as health care services, shopping malls or traditional markets, recreational centre, water supply and educational facilities is a major challenge of urban residents arising from inadequate access to transport infrastructure and transport services. According to them, poor urban residents including the elderly are affected by high cost of public transport, which in most cases are in short supply during peak transport period in first order cities like Lagos, Ibadan and Kano. The nature of road networks and transport services provided on them plays a prominent role in determining the level of accessibility of urban and rural dwellers to socio-economic facilities (Adesanya et., al (2002: p.261).

A careful search of literature on elderly accessibility to some urban facilities showed that focus is majorly on modes of transportation and distant travelled to access various locations. Most of these studies did not consider some important factors such as availability and patterns of urban facilities, distance travelled and transport fare in their studies on elderly accessibility to urban facilities. It is on this background that this study is designed to examine the distribution pattern of urban facilities and determine the extent of accessibility of senior citizens to health care providers and banks in a traditional but socially and economically developing city of Akure in South Western Nigeria.

\section{Study Area}

Akure metropolis is one of the ancient but economically developing cities in South Western Nigeria. The city is located on Latitude $715^{\prime}$ of the Equator and $5^{\circ} 12^{-} \mathrm{E}$ of the Greenwich 
Meridian. The city had a population of 239,124 in 1991 and increased tremendously to 269, 207 in 1996 (NPC, 1996) and also increased to 484, 798 in 2006(NPC, 2006, as cited in Ogunbodede and Ogundare, 2014). Shortly after Akure became the capital of Ondo State in 1976, the city witnessed rapid development in terms of population growth, economic activities and socio-economic facilities which include but not limited to traditional markets, ultra- modern markets, health care providers and banks (Ogunbodede and Ogundare, 2014). These soci-economic facilities can be regarded as urban facilities which are considered to be essential to the communities for human sustainable living.

Generally, the built up areas of Akure metropolis include Arakale, Ayedun Quarters, ljoka and Oja-Oba which are located in the core area of the city. These areas consist of more than 200 persons per hectare. The low density areas in Akure comprises ljagbo Quarters, Idofin, Igboba, Ibule and Onigari. Akure metropolis performs a number of functions to itself or neighbouring communities in South Western Nigerian. Some of these functions or services include education, commerce, social, recreation, financial institutions and health care delivery (Emenike and Ogunjobi, 2018). The accessibility of urban residents to some of these socio-economic facilities has led to high level of vehicular movement in the city which has in turn resulted in traffic delay and late arrival to various destinations (Emenike and Ogunjobi, 2018). In their study, Emenike and Ogunjobi (2018) further confirmed that Oyemekun and Arakale roads are the most congested routes in Akure, despite the fact that these routes were dualized in recent times with a view to accommodate more vehicular movement due to the fact that these two routes serve as distributors and collectors of traffic within Akure metropolis. The high traffic congestion in the city has made many of the urban commuters (children, adults and the elderly) to be less accessible to various destinations because of long distance travelled and time spent. Even though much research on travel behaviour of urban residents have been carried out in Akure, lle-Ife, Osogbo, Lokoja and many other medium sized cities in Nigeria, a study of elderly accessibility to urban facilities in Akure is very scanty in literature. If it exists at all, it is lumped with other household trip purposes. It is on this background that this study is designed to examine in detail the accessibility of senior citizens to urban facilities in the medium sized city of Akure.

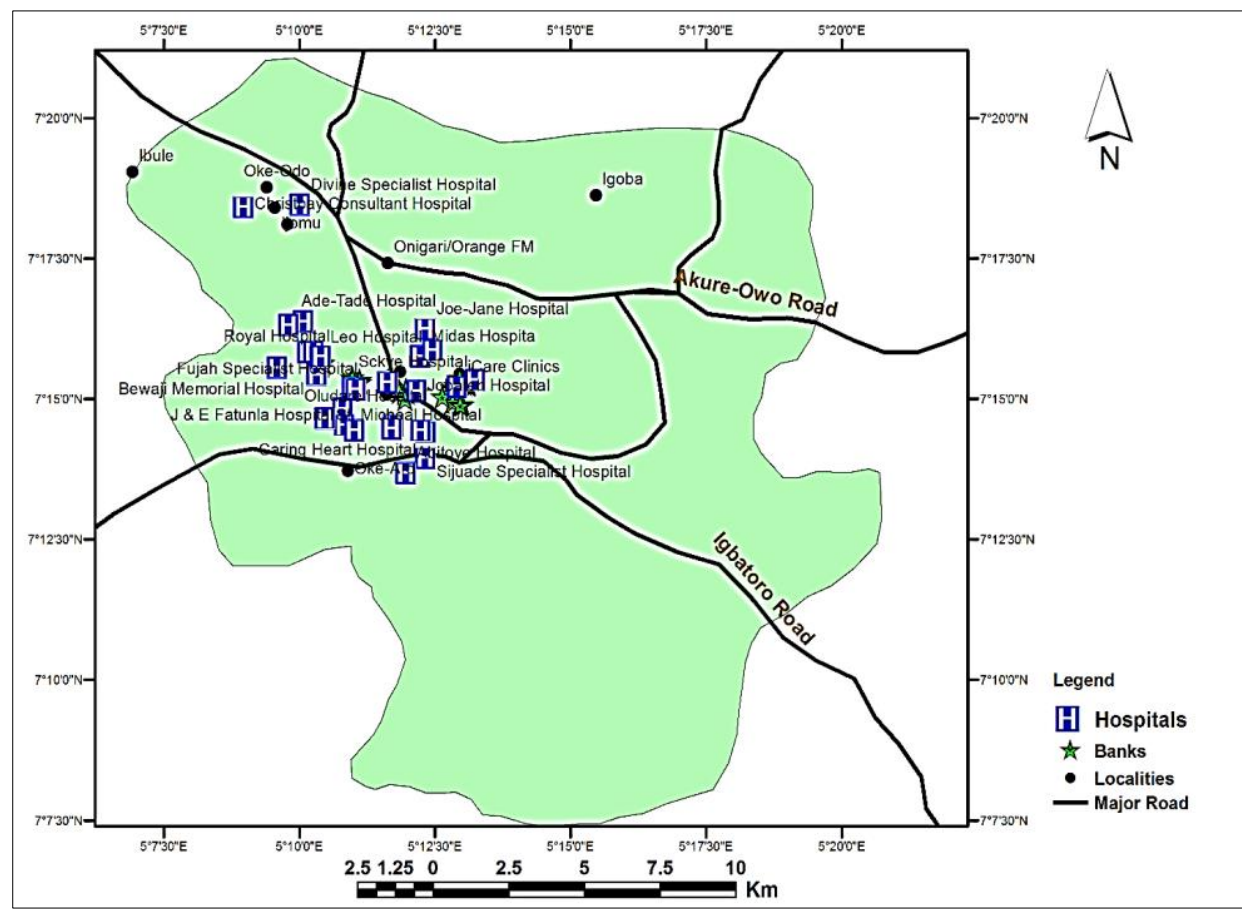

Figure 1: Distribution Patterns of Hospitals and Banks in Akure Metropolis 


\section{Materials and Methods}

\subsection{Materials}

An administrative map of Akure metropolis comprising Akure North and South sourced from the Ondo State Ministry of Land, Ondo State. Other relevant data include (i) important locations in Akure metropolis (ii) major urban facilities provided in the city such as public and private health care facilities, financial institutions such as banks. Coordinates of these basic facilities were obtained using a hand held Geographical Position System (GPS). These coordinates were subsequently plotted to produce point maps using the UTM, Zone 31, Minna datum coordinate system. The point maps produced were overlaid on the scanned administrative map which was used to produce (i) map showing the locations of public health care facilities in Akure, (ii) map showing the locations of private health care facilities in Akure and (iii) map showing the locations of the distribution patterns of banks in Akure. Furthermore, the average distance of the nearest public and private hospitals as well as banks to each of the important locations in Akure was measured using the 'Ruler' menu of ArcGIS 10.3.1. Furthermore, average nearest neighbourhood analysis was performed for the point data using the Spatial Statistics toolbox of ArcGis 10.3.1 software. Data on sociodemographic characteristics of senior citizens such as age, sex, possession of personal means of transport and income were obtained. Also, information relating to their travel patterns which included trip purposes, mode of transportation, cost of transportation and the challenges encountered during their journey purposes were solicited.

\subsection{Methods}

A Stratified sample technique was adopted to select thirteen different locations in Akure metropolis where elderly people mostly reside. A structured questionnaire was designed to elicit information on socio-demographic characteristics of elderly people and their travel behaviour as highlighted above. A systematic random sampling procedure was adopted in the administration of this questionnaire to the senior citizens. Elderly was selected for questionnaire administration in one in every fifth building along the major roads selected or sampled in the city. Once the initial household is selected others follows in a sequential manner.

\subsection{Method of Analysis}

Descriptive and inferential statistics were employed to analyse the data. Table of percentages and graphs were used to present the results of socio-demographic characteristics of the elderly and their travel patterns. Nearest Neighbour Analysis was employed to compute the average distance of the nearest urban facilities to important locations in Akure.

\section{Results and Discussion}

The age classification of older people sampled in Akure in Table 1a revealed that $60 \%$ are between 60 and $70 y e a r s, 31.4 \%$ are between 70 and 79 years. $8.6 \%$ of the senior citizen who are above 80years of age responded to the questionnaire administration. Also, more men $(55.1 \%)$ than women $(44.9 \%)$ were interviewed in the city. Less than $50 \%$ of the elderly interacted with have personal means of transport to engage in different trip purposes. The ability to drive their personal means of transport varies significantly amongst the elderly in the city. The Analysis of Variance in Table $1 \mathrm{~b}$ shows that it varies significantly across age groups among the elderly $(F=4.134,<.003)$. Also, Table $1 \mathrm{~b}$ revealed that between the ages of 60 
and $69,68.1 \%$ of the elderly indicated that they drive their personal vehicles to reach various urban facilities in Akure. Further analysis revealed that the elderly who are between the ages of 70 and $79,30.7 \%$ claim that they drive their personal vehicles to urban facilities. An insignificant proportion ( $0.9 \%)$ of elderly who are older than 80 years claimed that they travel using their personal vehicles. In terms of educational qualifications, 39.8\% of elderly do not have formal education, $11.7 \%$ have primary school leaving certificate. More than $40 \%$ of senior citizens have higher qualifications.

Table 1a: Socio-Demographic Characteristics of Elderly People in Akure (Author's Field Survey, 2019)

\begin{tabular}{|c|c|c|}
\hline Variables & Frequency & Percentage \\
\hline \multicolumn{3}{|l|}{ Age } \\
\hline $60-69$ years & 105 & 60.0 \\
\hline 70-79years & 55 & 31.4 \\
\hline More than 80year & 15 & 8.6 \\
\hline Total & 175 & 100.0 \\
\hline \multicolumn{3}{|l|}{ Gender } \\
\hline Male & 97 & 55.1 \\
\hline Female & 79 & 44.9 \\
\hline Total & 176 & 100.0 \\
\hline \multicolumn{3}{|l|}{ Educational Background } \\
\hline Non-formal & 68 & 39.8 \\
\hline Primary Leaving Cert. & 20 & 11.7 \\
\hline Secondary Sch Cert. & 34 & 19.8 \\
\hline HND/ B.Sc Degree & 49 & 28.7 \\
\hline Total & 171 & 100.0 \\
\hline \multicolumn{3}{|l|}{$\begin{array}{l}\text { Possession of Personal } \\
\text { Means of Transportation }\end{array}$} \\
\hline Yes & 79 & 45.1 \\
\hline No & 96 & 54.9 \\
\hline Total & 175 & 100.0 \\
\hline \multicolumn{3}{|l|}{$\begin{array}{l}\text { Ability to Drive Personal } \\
\text { Means of } \\
\text { among Different Ages of } \\
\text { Elderly }\end{array}$} \\
\hline 60 - 69years & 69 & 68.3 \\
\hline 70 - 79years & 31 & 30.7 \\
\hline$>80$ years & 1 & 1.0 \\
\hline Total & 101 & 100.0 \\
\hline
\end{tabular}


Table 1b: Analysis of Variance of Age Characteristics of Elderly and Driving Habit to Different Facilities (Author's Field Survey, 2019)

\begin{tabular}{lrrrrr}
\multicolumn{6}{c}{ ANOVA } \\
\hline Age & $\begin{array}{c}\text { Sum of } \\
\text { Squares }\end{array}$ & Df & $\begin{array}{c}\text { Mean } \\
\text { Square }\end{array}$ & F & Sig. \\
\hline Between & 6.328 & 4 & 1.582 & 4.134 & .003 \\
Groups & & & & & \\
Within Groups & 60.073 & 157 & .383 & & \\
Total & 66.401 & 161 & & & \\
\hline
\end{tabular}

\subsection{Trip to various Urban Facilities}

Senior citizens indicated that they engaged in different trips to some urban facilities in Akure metropolis. Table 2 reveals that $66.7 \%$ of the senior citizens engaged more in religious trips. This is because in African setting, elderly people move more closer to God than other age grouped because, they believed that they are moving towards their grave. Approximately $12.3 \%$ of the senior citizens escort their grandchildren to schools. Only $2.5 \%$ of the senior citizens claimed that they make trips to banks to withdraw their pension benefits or remittances from their relatives. Trip for shopping by the elderly is insignificant, as low as $1.3 \%$ of this category of people travel to the market. The result of this analysis is tangential to many studies on trip purposes by the elderly carried out in different parts of the world which reported that elderly people participated in different trip purposes(Olawole and Aloba, 2015; Ipingbemi, 2010, Mackkett, 2015).

Table 2: Urban Facilities most frequently Visited by Elderly Citizens (Author's Field Survey, 2019)

\begin{tabular}{lll}
\hline Trip Purposes & Frequency & Percentage \\
\hline Health Care Providers & 12 & 14.8 \\
\hline Shopping & 1 & 1.3 \\
\hline Religious & 54 & 66.7 \\
\hline Recreational Centre & 2 & 2.5 \\
\hline $\begin{array}{l}\text { Escorting Grand Children } \\
\text { to School }\end{array}$ & 10 & 12.3 \\
\hline Bank & 2 & 2.5 \\
\hline Total & 81 & 100.0 \\
\hline
\end{tabular}

The accessibility of senior citizens to some facilities located in urban space varies tremendously from one locality to another. Some elderly people travel short distances to have access to certain facilities or services located close to their residences while some travel to distant places to enjoy the same facilities or services. Table 3 indicates that no elderly people have access to public tertiary hospitals within $1 \mathrm{~km}$ radius to their residences. The mean distance travelled to public tertiary hospital in Akure metropolis is $3.36 \mathrm{~km}$. This can be considered to be a long trip and can be classified as higher order service. Elderly citizens residing at Oke - Aro, Arakale, Lafe, Isolo and Adegbola Quarters have access to public tertiary hospitals within $2 \mathrm{kms}$ radius from their residences. Elderly citizens living at peri-urban areas of Akure metropolis particularly at ljomu, Oke-Odo, Ibule and Igoba travel an average of $3.9 \mathrm{Km}, 4.6 \mathrm{~km}, 7.3 \mathrm{~km}$ and $9.7 \mathrm{~km}$ to access public tertiary hospital services and facilities in the city respectively. The result of Nearest Neighbour Analysis in Figure (2a) (p.15) reveals that the Observed Mean Distance travel to access public tertiary hospital services and facilities at Akure metropolis is 1002.3346 metre, while the Expected Mean Distance travel is 585.2432 metres. The positive Z-Score $=3.339653$ with $\mathrm{P}$-value $=0.000839$ 
indicate that public tertiary hospital facilities is dispersed rather than random, which accounts for long distance trip to access this health care facility in the city.

In terms of access to primary health care facilities in the city, Table 3 reveals that the Mean Distance Travelled is $1.60 \mathrm{~km}$. Many of these primary health care facilities are owned by private individuals and organisations and are generally concerned with the provision of medical services to those patients with mild cases of illness. Senior citizens that live at ljomu, Orita - Obele, Oja-Oba, Arakale, Adegbola, Isolo, Lafe and Champion localities have access to primary health care facilities within $1 \mathrm{~km}$ to their residences. Figure $2 \mathrm{~b}$ reveals that the Observed Mean Distance travel to primary health facility is 690.1945 metres, while the Expected Mean Distance travel is 70.1707 metres and the Nearest Neighbour Ratio is: 0.981546 . Given the Z-score of -0.169309 , the pattern of distribution of primary health facilities available at Akure metropolis does not appear to be significantly different at random, hence elderly people travel short distances to access this facility. Although in few localities, particularly at Igoba and lbule, the elderly citizens living in these areas are less accessible to neither public tertiary hospitals nor primary health facilities because the distance to any health care facilities in these localities are $9.7 \mathrm{~km}$ and $7.3 \mathrm{~km}$ respectively.

With respect to trip to bank, Table 3 reveals that the Mean Distance Travel to Banks in Akure metropolis is $2.42 \mathrm{~km}$. Senior citizens who reside at Oja -Oba, Arakale, Adegbola, Lafe, and Isolo Quarters have access to banking services to withdraw their pension benefits within $1 \mathrm{~km}$ radius from their residences. Elderly citizens who live at ljomu, Oke-Odo, Ibule and Igboba need to travel for more than $5 \mathrm{kms}$ to access banking services. This implies that some senior citizens are less accessible to banking services within walkable distances in Akure metropolis. It can be deduced that the provision of banking services can be regarded as higher order goods and services where prospective customers would commute long distances to access such services. Figure $2 \mathrm{c}$ reveals that the Observed Mean Distance travel to bank is 168.7686 metres, while the Expected Mean Distance is $213.8267 m e t r e s$, with Zscore of -2.055551 and P-Value of 0.039826 . This buttressed the fact that the pattern of distribution of banking facility in Akure seems to be more clustered rather than random.

Table 3: Distance to Some Urban Facilities (Author's Field Survey, 2019)

\begin{tabular}{llll}
\hline Location of Places & Public Hospital & $\begin{array}{l}\text { Private Owned } \\
\text { Hospital/ Primary } \\
\text { Health Centre }\end{array}$ & Banks \\
\hline ljomu & 3.889 & 0.9 & 5.3 \\
\hline Oke-Odo & 4.584 & 1.03 & 6.1 \\
\hline Orita-Obele & 3.312 & 0.8 & 4.7 \\
\hline Oja-Oba & 2.239 & 0.4 & 0.1 \\
\hline Oke-Aro & 1.335 & 1.5 & 2.9 \\
\hline Arakale & 1.054 & 0.4 & 0.4 \\
\hline Adegbola & 1.707 & 0.4 & 0.9 \\
\hline Ibule & 7.312 & 3.948 & 8.9 \\
\hline Igoba & 9.701 & 7.272 & 7.3 \\
\hline Lafe & 1.138 & 0.8 & 0.6 \\
\hline Isolo & 1.769 & 0.5 & 0.6 \\
\hline Champion & 1.657 & 0.2 & 0.3 \\
\hline Onigari/Orange FM & 3.933 & 2.6 & 3.9 \\
\hline Total & 43.63 & 20.75 & 31.4 \\
\hline Mean Distance & 3.36 & 1.60 & 2.42 \\
\hline
\end{tabular}


The main mode of transport in urban centres in Nigeria is by foot particularly when short distances are involved (Olawole and Aloba, 2014). Table 4 reveals that $10.3 \%$ of the elderly trek to reach many urban facilities in Akure metropolis. The purpose of trips determine to a large extent the mode of transportation used. Taxi and motorcycle recorded the highest (30.2\% each) mode of transportation patronised by the elderly to reach various facilities in the city. Only $25 \%$ of the elderly travelled using their personal vehicles to reach urban facilities in the study area. More than $60 \%$ of the elderly rely on public transport services to access various urban facilities. The result of this analysis is at variance the some studies carried out in some developed countries where personal cars are the principal mode of transport that old people use for their trip purposes(Collia et al., 2003; Mercado and Newbold, 2009; Schmocker et al., 2008 as cited in Mifsud; Attard and Ison, 2017).

Table 4: Mode of Transportation by the Elderly to Different Urban Facilities in Akure Metropolis (Author's Field Survey, 2019)

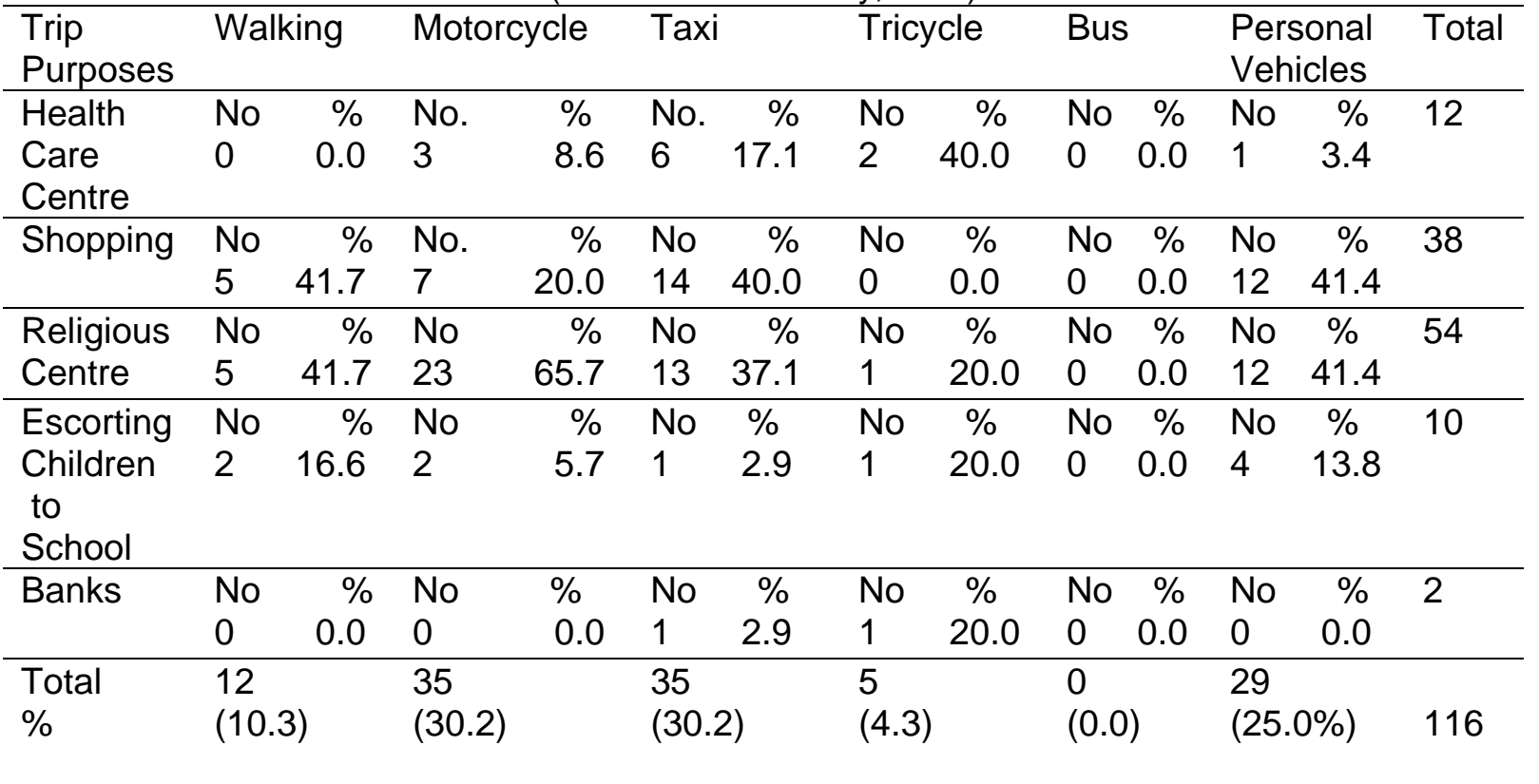

In view of the distances travelled and modes of transportation used to reach various locations where various urban facilities are located, the transport fares differ. Public transport operators normally charge low transport fare for short distances. The longer the distance travelled, the higher the transport fare paid to reach such location and therefore the less accessible such destination may likely be. Table 5 reveals that $28.8 \%$ of senior citizens paid less than one hundred naira( $\$ 100)$ as transport fare to reach various urban facilities in Akure metropolis. More than $50 \%$ of the senior citizens claimed that they paid between one hundred naira ( 100 ) and two hundred naira( $\$ 200)$ for their trips to various locations. These transport fares paid by the senior citizens for their trips to various urban facilities can be considered to be very high because of the poor economic situation in Nigeria where $70 \%$ of the population live on $\$ 1.25$ or less per day (World Bank, 2014). Besides, most elderly citizens are retirees and belong to the dependant age group. Such high transport fare to reach basic urban facilities may limit the accessibility of people especially the elderly to such facilities. Only $0.9 \%$ of the elderly indicated that they spent more than 300 on their trips to some urban facilities in Akure. These elderly people reside at low density areas of the city particularly at Igoba, Ibule and Oke Odo where some basic urban facilities are lacking. 
Table 5: Transport Fares Incurred by Elderly for Different Journey Purposes (Author's Field Survey, 2019)

\begin{tabular}{llcllllll}
\hline \multicolumn{10}{c}{ Transport Fare } \\
\hline Trip Purpose & Less than & $\mathbf{1 0 0}$ & $\mathbf{1 0 1} \mathbf{1 0 0}$ & $\mathbf{2 0 1}$ & $\mathbf{3 0 0}$ & \multicolumn{2}{c}{ More } & $\mathbf{3 0 0}$ \\
\hline Health Care & No. & $\%$ & No. & $\%$ & N0. & $\%$ & No. & $\%$ \\
Centre & 1 & 2.2 & 9 & 13.2 & 1 & 50.0 & 1 & 100.0 \\
\hline Shopping & No. & $\%$ & No. & $\%$ & No. & $\%$ & No. & $\%$ \\
Centre/Market & 23 & 51.1 & 15 & 22.2 & 0 & 0.0 & 0 & 0.0 \\
\hline Religious & No. & $\%$ & No. & $\%$ & No. & $\%$ & No. & $\%$ \\
Centre & 17 & 37.8 & 36 & 52.9 & 1 & 50.0 & 0 & 0.0 \\
\hline School Trips & No. & $\%$ & No. & $\%$ & No. & $\%$ & No. & $\%$ \\
& 4 & 8.9 & 6 & 8.8 & 0 & 0.0 & 0 & 0.0 \\
\hline Banks & No. & $\%$ & No. & $\%$ & No. & $\%$ & No. & $\%$ \\
& 0 & 0.0 & 2 & 2.9 & 0 & 0.0 & 0 & 0.0 \\
\hline Total & 45 & $(38.8)$ & 68 & $(58.6)$ & 2 & $(1.7$ & 1 & $(0.9)$ \\
\hline
\end{tabular}

The travel time taken to reach various locations is an important variable used to determine the level of accessibility of people to different destinations. Table 6 reveals that $29.2 \%$ of the elderly indicate that they spent less than 10 minutes to reach some basic facilities in Akure. Approximately $59.3 \%$ of the elderly spent between 10 and 30 minutes on their transit to different facilities. Table 6 further reveals that $11.5 \%$ of the senior citizens spend between 31 and 60 minutes to access some urban facilities in Akure.

Table 6: The Elderly Travel Time to Different Urban Facilities (Author's Field Survey, 2019)

\begin{tabular}{|c|c|c|c|c|c|}
\hline $\begin{array}{l}\text { Trip } \\
\text { Purposes }\end{array}$ & $\begin{array}{l}\text { Less than } \\
10 \text { mins }\end{array}$ & $10-30$ mins & $31-60$ mins & $\begin{array}{l}\text { More } \\
60 \mathrm{~m}\end{array}$ & \\
\hline $\begin{array}{l}\text { Health Care } \\
\text { Centre }\end{array}$ & $\begin{array}{ll}\text { No. } & \% \\
1 & 3.0\end{array}$ & $\begin{array}{r}\% \\
11.9\end{array}$ & $\begin{array}{c}\% \\
23.1\end{array}$ & $\begin{array}{l}\text { No. } \\
0\end{array}$ & $\begin{array}{l}\% \\
0.0\end{array}$ \\
\hline Shopping & $\begin{array}{r}\% \\
36.4 \\
\end{array}$ & $\begin{array}{r}\% \\
37.3 \\
\end{array}$ & $\begin{array}{l}\text { No. } \\
1\end{array}$ & $\begin{array}{l}\text { No. } \\
0\end{array}$ & $\begin{array}{l}\% \\
0.0\end{array}$ \\
\hline $\begin{array}{l}\text { Religious } \\
\text { Centre }\end{array}$ & $\begin{array}{lr}\text { No. } & \% \\
16 & 48.5\end{array}$ & $\begin{array}{r}\% \\
43.3 \\
\end{array}$ & $\begin{array}{c}\% \\
53.8\end{array}$ & $\begin{array}{l}\text { No. } \\
0\end{array}$ & $\begin{array}{r}\% \\
0.0\end{array}$ \\
\hline School Trip & $\begin{array}{r}\% \\
12.1 \\
\end{array}$ & $\begin{array}{l}\text { No. } \\
5\end{array}$ & $\begin{array}{l}\text { No. } \\
0\end{array}$ & $\begin{array}{l}\text { No. } \\
0\end{array}$ & $\begin{array}{l}\% \\
0.0\end{array}$ \\
\hline Banks & $\begin{array}{lr}\text { No. } & \% \\
0 & 0.0\end{array}$ & $\begin{array}{l}\text { No. } \\
0\end{array}$ & $\begin{array}{c}\% \\
15.4\end{array}$ & $\begin{array}{l}\text { No. } \\
0\end{array}$ & $\begin{array}{r}\% \\
0.0\end{array}$ \\
\hline Total & $\begin{array}{l}33100.0 \\
(29.2)\end{array}$ & $\begin{array}{ll}67 & 10.0 \\
(59.3)^{2}\end{array}$ & $\begin{array}{l}13100.0 \\
(11.5)^{13}\end{array}$ & $\begin{array}{l}0 \\
(0.0)\end{array}$ & \\
\hline
\end{tabular}




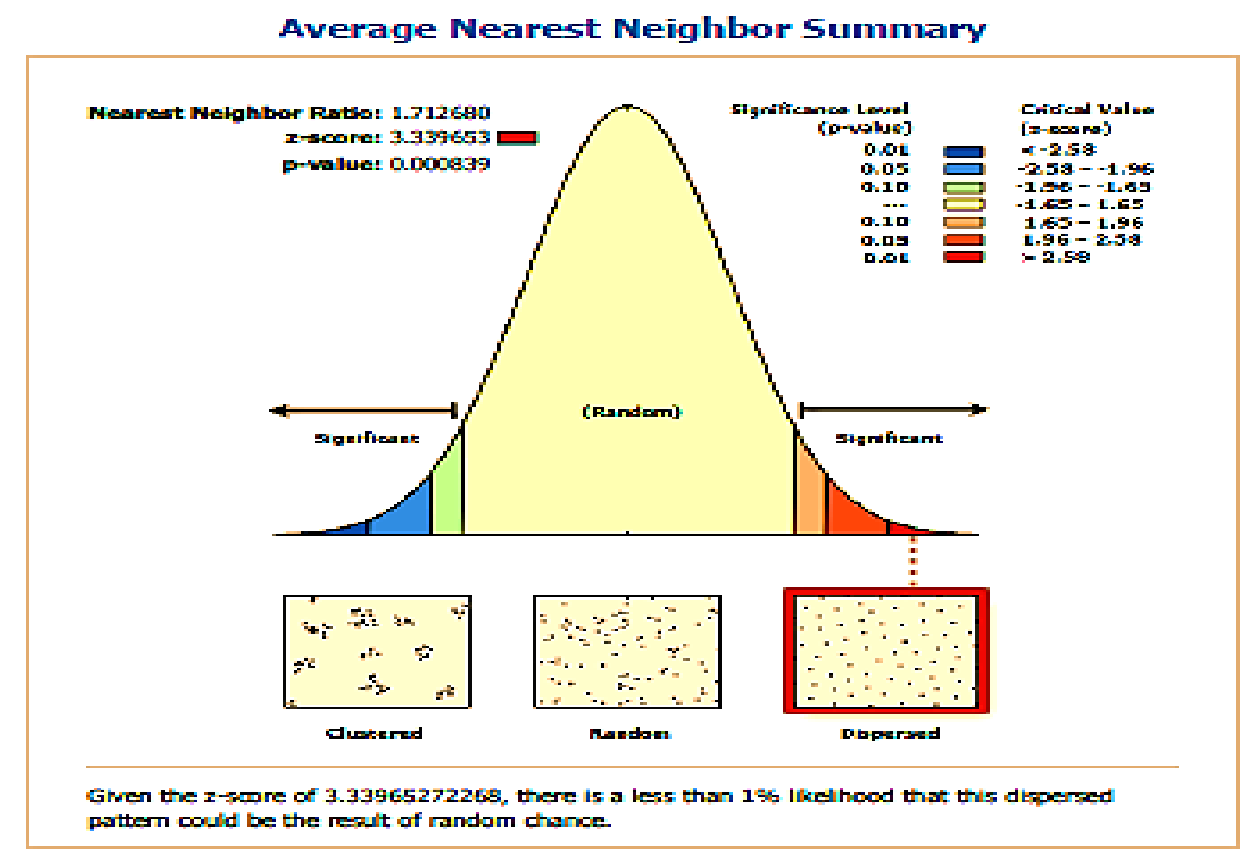

Average Nearest Neighbor Summary

\begin{tabular}{|r||l|}
\hline Observed Mean Distance: & 10023346 Meters \\
\hline Expected Mean Distance: & 585.2432 Meters \\
\hline Nearest Neighbor Ratio: & 1.712680 \\
\hline z-score: & 3.339653 \\
\hline p-value: & 0.000339 \\
\hline
\end{tabular}

Dataset Information

\begin{tabular}{|r|l|l|}
\hline Input Feature Class: & Akure_Public_Health_Facilies_Profected \\
\hline Distance Method: & EUCUIDENN \\
\hline Study Area: & a220231.700469 \\
\hline Selection Set: & False \\
\hline
\end{tabular}

Figure 2a: Pattern of Distribution of Public Tertiary Hospitals in Akure Metropolis (Author's Field Survey, 2019) 


\section{Average Nearest Neighbor Summary}

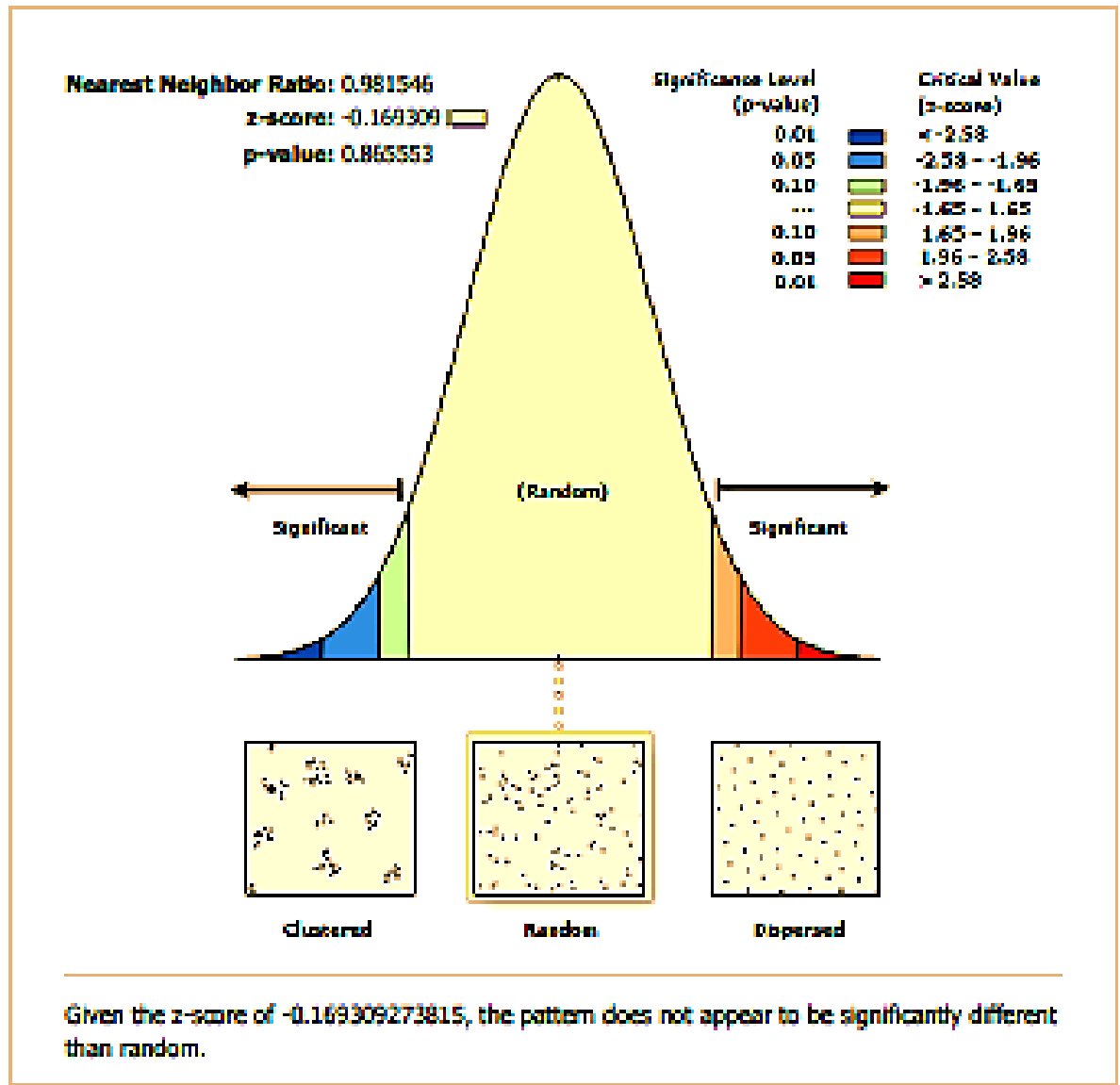

Average Nearest Neighbor Summary

\begin{tabular}{|r|l|}
\hline Observed Mean Distance: & 690.1945 Meters \\
\hline Expected Mean Distance: & 703.1707 Meters \\
\hline Nearest Neighbor Ratio: & 0.981546 \\
\hline z-score: & -0.169309 \\
\hline p-value: & 0.865553 \\
\hline
\end{tabular}

\section{Dataset Information}

\begin{tabular}{|r|l|}
\hline Input Feature Class: & Nkure_Private_Hospital_Projected \\
\hline Distance Method: & EUCLDENN \\
\hline Study Area: & 45489309.860237 \\
\hline Selection Set: & False \\
\hline
\end{tabular}

Figure 2b: Pattern of Distribution of Primary Health Care in Akure Metropolis (Author's Field Survey, 2019) 


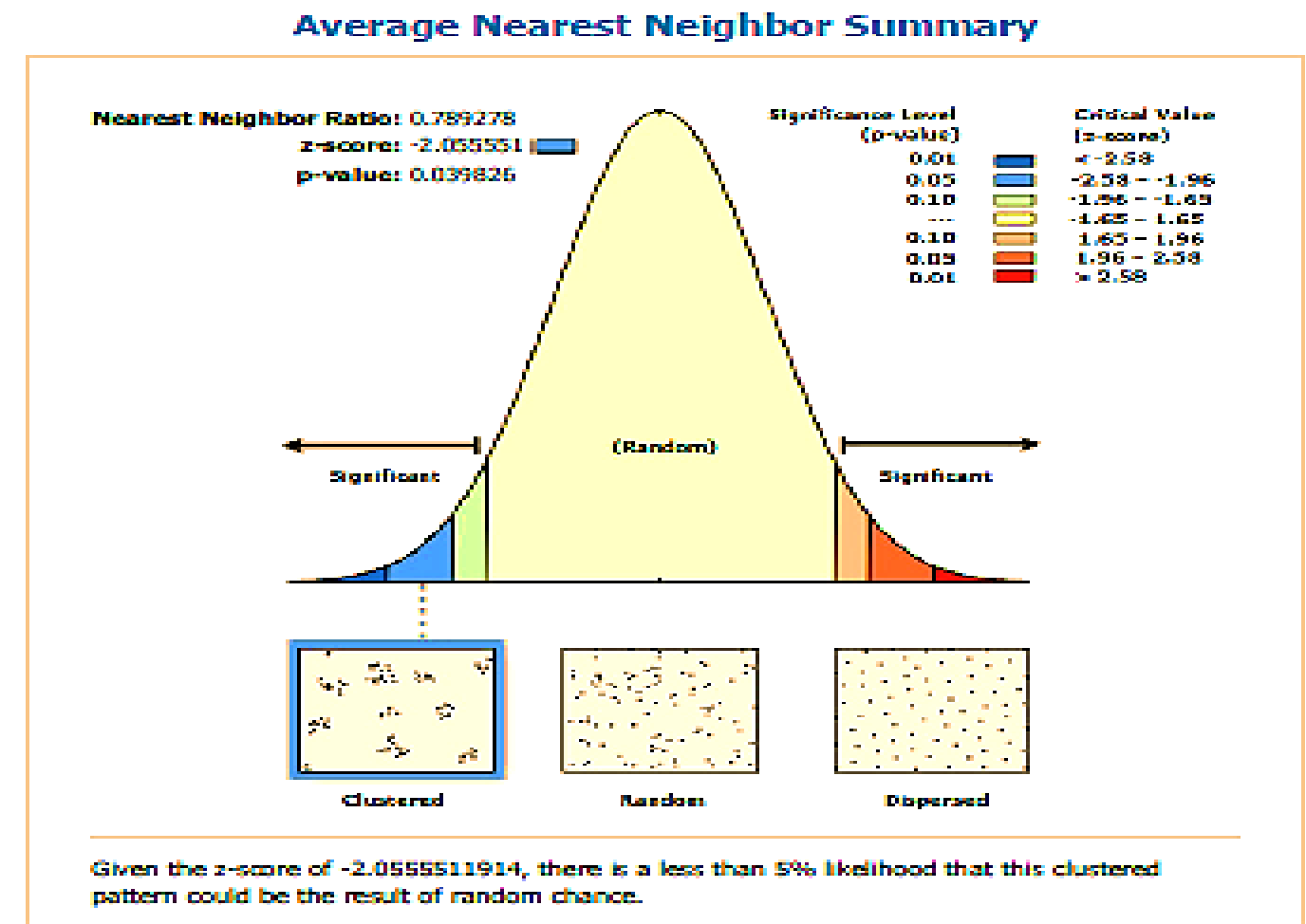

Average Nearest Neighbor Summary

\begin{tabular}{|r|l|l|}
\hline Observed Mean Distance: & 168.7685 Meters \\
\hline Expected Mean Distance: & 213.8267 Meters \\
\hline Nearest Neighbor Ratio: & 0.769278 \\
\hline z-score: & -2.055551 \\
\hline p-value: & 0.039325 \\
\hline
\end{tabular}

Dataset Information

\begin{tabular}{|r|l|l|}
\hline Input Feature Class: & Akure_Eanks_Projected \\
\hline Distance Method: & EUCLDENN \\
\hline Study Area: & 4755071.049644 \\
\hline Selection Set: & False \\
\hline
\end{tabular}

Figure 2c: Pattern of Distribution of Banking Facility in Akure Metropolis (Author's Field Survey, 2019)

\subsection{Challenges Encountered by the Elderly on their Trips to Urban Facilities}

Older people are faced with many problems during their trips to different activity centres. Studies have shown that senior citizens that rely on public transport suffer from social exclusion due to difficulties encountered when travelling to access facilities or services (Engel and Liu 2011; Shergold and Parkhurst, 2012). Other challenges faced by the elderly in accessing urban facilities or services are traffic delay, long waiting time to access public transport and environmental pollution. Table 7 reveals that $65.9 \%$ of older people in Akure metropolis claim that traffic delay is the major challenge they encounter in order to access basic facilities in the city. Heavy traffic delay occurs along the main arterial roads in Akure particularly on Oyemekun, Alagbaka and Arakale roads. This is because many urban facilities such as banks, markets and supermarkets are located along these routes. Emenike 
and Ogunjobi (2018) reported that illegal parking, bad roads and vehicle break downs are major causes of traffic congestions in Akure. $10 \%$ of older people indicated that environmental problems such as indiscriminate use of horns by public transport operators to scare other road users during heavy traffic is the major challenge encountered during their trips to basic facilities in the city. Long period of waiting for public transport services and overloading of passengers during their trips accounted for $9.4 \%$ and $8.2 \%$ respectively. Road traffic crashes recorded only $3.5 \%$ of the problems raised among the factors affecting their accessibility to urban facilities.

Table 7: Problems Faced by the Elderly People in Effective Utilization of Basic Facilities (Author's Field Survey, 2019)

\begin{tabular}{lll}
\hline $\begin{array}{l}\text { Variable of Transport } \\
\text { Problems Identified }\end{array}$ & Frequency & Percentage \\
\hline Traffic Delay & 112 & 65.9 \\
\hline Overloading & 14 & 8.2 \\
\hline Road Traffic Crashes & 6 & 3.5 \\
\hline $\begin{array}{l}\text { Difficulties Boarding Public } \\
\text { Transport Services During }\end{array}$ & 5 & 3.0 \\
Peak Period & \\
\hline $\begin{array}{l}\text { Long Waiting Time for } \\
\text { Public Transport Services }\end{array}$ & 16 & 9.4 \\
\hline Environmental Pollution & 17 & 10.0 \\
\hline Total & 170 & 100.0 \\
\hline
\end{tabular}

\section{Conclusion and Implications for Planning}

The study assessed the accessibility of the elderly to some basic urban facilities in Akure metropolis. At the introductory part of the research, effort was made to review the existing literature on accessibility of senior citizens to facilities located in geographical space and discuss how efficient transport services can promote and alleviate transport burden of the elderly citizens in accessing facilities in urban areas. Primary and secondary data were utilised for the study. Geographical Position System was used to take the coordinates of some important facilities such as health care, facilities and banks. Nearest Neighbour Analysis was employed to compute the Mean Distance Travel to public tertiary hospital, primary health facilities and banks in the city. Findings reveal that the distribution patterns of public tertiary hospitals in Akure are dispersed rather than random. Hence, many urban residents including the elderly travel long distances in order to access these facilities. The Mean Distance Travel to access primary health facilities in Akure is $1.60 \mathrm{~km}$. This can be considered to be short when compared with public tertiary hospital with Mean Distance travel of $3.36 \mathrm{~km}$. More than $60 \%$ of the elderly rely on public transport services for their trips to access basic facilities in the city. Traffic delay was ranked highest (66\%) among the problems militating against the effective utilisation of urban facilities in Akure metropolis. Environmental problems such as indiscriminate use of horns and emission of toxic substances from motorized vehicles was ranked second (10\%) among the problems encountered by the elderly on their trip purposes. Other problems identified by the senior citizens are long waiting time for public transport vehicles, overloading and road traffic crashes. The study recommends that more basic urban facilities such as public tertiary hospitals, banks and markets be provided in localities where such facilities are lacking .This will reduce long distance trip to these facilities in the city. The study concludes that better transport services should be made available at reasonable transport fare. This will promote 
effective utilisation of urban facilities by the elderly and other segments of the population in Akure and similar other cities in Nigeria.

\section{Acknowledgement}

I hereby acknowledge the effort of Mr Awoniran Dauda of the Department of Remote Sensing, Federal University of Technology Akure, Nigeria for updating the map of the study area.

\section{References}

Adesanya, A., Adeniji, K. Daramola, A.Y. (2002). Transport Perspective of Poverty in Nigeria in Poverty In Nigeria. A Multi- Dimensional Perspectives edited by D. Olu Ajakaiye and Ade S. Olomola.

Collia, D.V., Sharp, J., Gresbrecht, L. (2003). The 2001 National Household Travel Survey: A Look into the Travel Patterns of Older Americans. Journal of Safety Research 34, 461470

Cui, M., Levinson, D. (2018). Full cost accessibility. The Journal of Transport and Land Use, 11 (1): 661-679.

Duvarci, Y., Yigitcanlar, Y., Alver, Y and Mizokami, S. (2010). Variant Concept of Transportation-Disadvantage: Evidence from Aydin, Turkey, and Yamaga, Japan. Journal of Urban Planning and Development, 137(1), 82-90.

Emenike, G.C., Ogunjobi, O.S. (2018). Commuting Pattern and Transportation Challenges in Akure Metropolis, Ondo State. New York Science Journal, Volume 11(1): 3541.

Fitzpatric, A., Powe, N. R., Cooper, L.S., Ives, and Robbins, J. A.(2004). Barrier to Health Care Access among the Elderly and who Perceives Them. American Journal of Public Health. V. 94 (10), October, 2014. Available online at https://www.ncbi.nlm.nih.gov/pmc/articles/PMC1448535/. Accessed on 13/11/2018

Geurs, K.T., Wee, B. Van. (2004). Accessibility Evaluation of Land Use and Transport Strategies: Review and Research Directions. Journal of Transport Geography, 1 2(2004) 127-140

Giuliano, G. (2005). Low Income, Public Transit and Mobility. Transport Research Record: Journal of Transportation Research Board, 1927, 63-70.

Mackett, R. (2015). Improving Accessibility for Older People - Investing in a Valuable Asset Journal of Transport \& Health. (2015) 5-13.

Mercado, R., Newbold, K. B.( 2009). Car Driving and Public Transit Use in Canadian metropolitan Areas: Focus on Elderly and Role of Health and Social Network Factors. SEDAP Research Paper No.243.

Mifsud, D., Attard, M., Ison, S . (2017). To Drive Or To Use The Bus? An Exploratory Study of Older People in Malta. Journal of Transport Geography 64(2017)23-32.

Musselwhite, C., Haddad, H. (2010). Mobility, Accessibility and Quality of Life. Quality Ageing Adult 11(1), 25-37

National Population Commission (NPC, 2006). National Population Census of the Federal Republic of Nigeria, http://www.google.com/search?client=firefox-, accessed 10.04.2017.

Ogunbodede, E.F., Ogundare, B.A.( 2014). Intra-Urban Parking Capacities and Parking Demands in Akure, Ondo State. European Environmental Sciences and Ecological Journal, Volume 1(1)1-10.

Olawole, M. O., Aloba, O. (2014). Mobility Characteristics of the Elderly and Their Associated Level of Satisfaction with Transport Services in Osogbo, South-western Nigeria. Transport Policy 35(2014) 105-116.

Owen, A., Lewinson, D.( 2014). Access across America: University of Minnesota Ranks Accessibility to Jobs by Transit. Available at: https://mntransportationresearch.org/2014/10/07/access-across-america-university- ofminnesota-ranks-accessibility-to-jobs-by-transit-in-top-u-s-cities/. Accessed on 10/11/2018 
Paez, A., Mercado, R.G., Farber, S., Morency, C., Roorda, M. (2010). Accessibility to Health Care Facilities in Montreal Island: An Application of Relative Accessibility Indicators from the Perspective of Senior and Non-Senior Residents. International Journal of Health Geographics, 2010, 1-15.

Srichuae, S., Nitivattananon, V.,Perera, R. (2016). Aging Society in Bangkok and The Factors Affecting Mobility of Elderly in Urban Public Spaces And Transportation Facilities. Elsevier Limited on behalf of International Association of Traffic and Safety Sciences. 40 (2016) 26-34.

Shergold, I., Parkhurst, G.(2012). Transport-Related Social Exclusion amongst Older People in Rural Southwest England and Wale. Journal of Rural Studies. 28 (4), 412-421. Special Issue on Growing Old in Rural Places.

World Bank (2014): World Bank on poverty in Nigeria. Poverty and Transportation: A way forward.

Yang Ya-ting., Iqbal Usman., Ko Hua-Lin., Wu Chia-Rong,. Chiu Hsien - Tsai Chiu., Lin YiChieh., Lin Wender and Hsu Yi-Hsin Elsa Hsu.(2015). The Relationship between Accessibility of Healthcare Facilities and Medical Care Utilisation among the Middle Aged and Elderly Population in Taiwan. International Journal for Quality in Health Care, 2015, 27(3)222-231.

Yi Zhang, Wei Wu, Qian He, and Chaoyang Li. (2018). Public Transport Use Among the Urban And Rural Elderly in China: Effects of Personal, Attitudinal, Household, Social -Environment And Built -Environment. The Journal of Transport and Land Use, 11 (1): 701-719. 